\title{
Mental health among displaced and non-displaced populations in Valledupar, Colombia: Why do inequities continue?
}

Sonia Diaz Monsalve ( $\square$ sonia.diaz.monsalve@zmg.uni-freiburg.de)

Albert-Ludwigs-Universitat Freiburg https://orcid.org/0000-0002-2308-525X

Angélica María Vargas-Monroy

Pontificia Universidad Javeriana

Jannethe Esmeral Ariza

Secretaria de Salud Departamental del Cesar

Ana Maria Oñate Cuello

Secretaria de Salud Municipal de Valledupar

Ana Rosa Ropero Vera

Secretaria de Salud Departamental del Cesar

Juan Carlos Bermudez Cuello

Secretaria de Salud Municipal de Valledupar

Lina Arzuaga Zuleta

Secretaria de Salud Departamental del Cesar

Andrés Felipe Cubillos Novella

Pontificia Universidad Javeriana

Enrique Peñaloza Quintero

Pontificia Universidad Javeriana

Yesika Natali Fernández Ortiz

Pontificia Universidad Javeriana

Axel Kroeger

Albert-Ludwigs-Universitat Freiburg

Research article

Keywords: Mental health, displaced populations, inequity, Colombia

Posted Date: July 24th, 2020

DOl: https://doi.org/10.21203/rs.3.rs-27875/v2 
License: (c) (i) This work is licensed under a Creative Commons Attribution 4.0 International License. Read Full License 


\section{Abstract}

Background: During the long lasting civil war in Colombia involving several armed groups, the year 2002 marked a peak of violent activities displacing thousands of people mainly from rural to urban areas, causing social disruption and prolonged poverty. In 2015, the Colombian national survey on mental health provided a first overview of mental health problems of victimized families and individuals (macro level). The here presented study aimed at analysing ongoing inequalities regarding displaced and nondisplaced populations in Cesar State (micro level), one of the most affected areas by the armed conflict.

Methods: An interview survey was conducted among 211 displaced families and 181 non-displaced families in 2 adjacent compounds with several five-storey buildings in the outskirts of Valledupar, the capital of Cesar State in Colombia. The questionnaires were developed together with and applied by staff of the health and social services of the departmental secretary of health. The 15 interviewers conducted additionally in-depth interviews and participant observations.

Results : The peak of internal displacement occurred around the year 2002, affecting disproportionally more the afro-descendent and indigenous populations. However, the marginalization of previously displaced persons is still ongoing. The living conditions in the neighbourhood of the displaced community were quite precarious in terms of lack of security, continuous noise, drug trafficking and poor connection with public transport. Consequently, psycho-emotional problems were more frequent among the displaced compared to the non-displaced neighbourhood. The displaced had experienced more violent acts (intended murder, threat, murder of a family member and kidnapping) and had subsequently a larger number of emotional symptoms (fright, headache, nervousness, depression, sleeplessness). Other stress factors like economic problems, severe disease or death of family members and unemployment prevailed in the community of displaced persons compared to the non-displaced. Nondisplaced lived in a more protected environment and were less exposed to violence and stress, although belonging to a similarly low socio-economic stratum. It is recommended to take measures for a better protection of the displaced community, improve their access to the job market, offer different leisure activities (sports club, art, women's club) and facilitate public transport.

\section{Background}

Civil war is a sad reality of many countries in our contemporary world and Colombia is a prominent example among them. Colombia with a total population of roughly 50 million inhabitants has suffered an armed conflict among different interest groups for several decades, which partially ended in 2016 with the peace treaty of the government with FARC (Fuerzas Armadas Revolucionarias de Colombia, Colombian Revolutionary Armed Forces), one of the major guerrilla groups. More than five million Colombian citizens have suffered violence and internal displacement during this time affecting their mental health and well-being and creating high levels of headache, sadness, nervousness, suicidal attempts and depression (National Mental Health Survey, Encuesta Nacional de Salud Mental -ENSM 2015). The situational analysis of the health situation in Colombia has shown that the internal 
displacement has generated vulnerability and affected the physical and even more the mental health of the families involved (ASIS 2016). According to the national Programme for Attending Psychosocial and Integral Health among Victims (PAPSIVI) the armed conflict has generated a deterioration of living conditions among these groups creating distrust, insecurity and fear (PAPSIVI 2013).

According to the Central Register of Victims, the State of Cesar is one of the most affected States (departamentos) by the armed conflict in the country (RUV 2018). According to this source, the State has more than 300,000 victims, $85 \%$ of them being displaced. In Valledupar, the capital of the State, 132.294 victims were registered in July 2018 mainly living in neighbourhoods with high insecurity levels and crime. In spite of these problems, no detailed information is available which could help to plan a better future for these communities. Health and social workers operating in these neighbourhoods are aware of problems but do not have concrete information about the real dimension of human suffering which can directly lead to action.

In order to understand the burden of the psycho-social challenges among displaced families or those subject to other forms of violence by the armed conflict, the here presented study was set up jointly by the State Health Services in Cesar and universities in Colombia (Instituto de Salud Pública de la Pontificia Universidad Javeriana) and Germany (Freiburg University, Centre for Medicine and Society) supported by the German Academic Exchange Service (DAAD). The objective was to quantify the burden of mental health issues among displaced and victimised persons in comparison with non-displaced persons of a similar socio-economic status living in the same environment in order to design programmes for improving the situation.

\section{Methods}

\section{Study communities}

Both study communities were located next to each other in a suburb of Valledupar.

Displaced community: The neighbourhood of Hernando Marín was constructed in the outskirts of Valledupar by the national Government as part of a social programme to provide shelter to poor displaced families (belonging to stratum 1 to 2 in the Colombian socio-economic classification system where stratum 5 represents the highest level). Six blocks of five-storey buildings with a total of 1900 departments were built, each apartment having a surface area of $45.6 \mathrm{~m} 2$ (see Fig. 1). The families can live there for free and have only to pay for water, electricity, gas, and administration.

Non-displaced community: The neighbourhood Leandro Diaz was part of a governmental housing programme for employees of the lower socio-economic level (stratum 2). It has three blocks, each with six five-storey buildings, in total 1300 apartments. A fence secures the buildings and a security guard controls the entrance (see Fig. 1). The families must pay a subsidized rent plus expenses for basic services (water, electricity, gas, administration). 
A mixed method approach was applied with quantitative elements (questionnaire survey) and qualitative elements (observational study).

\section{Questionnaire survey}

The interview survey was conducted among 211 displaced families and 181 non-displaced families living in two adjacent compounds. The survey was only applied to adults who provided information related to the purpose of this study. No child or adolescent below the age of 18 was interviewed in this study (see declarations). The questionnaires were developed together with 15 staff members of the health and social services of the State Secretary of Health. The questions were a selection of the most relevant questions used in the national survey on mental health (ENSM 2015), except for the introductory questions for the characterization of the study populations.

The simple size was calculated using data from the national mental health survey on the difference of proportions of major mental health issues in displaced families compared to the non-displaced. With a confidence level of $95 \%$, a power of $80 \%$ and a cumulative prevalence of major emotional problems among the displaced versus non-displaced populations of $55 \%$ versus $30 \%$ respectively, a minimum simple size of 170 families per study arm was calculated, but finally 211 displaced and 181 nondisplaced families were interviewed. Using systematic sampling, the sampling interval in the displaced families was nine (every ninth family to be interviewed) and in non-displaced it was eight (every eighth family to be interviewed).

After pre-testing the questionnaire, the leaders of both communities were informed and consulted in separate meetings and their consent was obtained as well as their willingness to inform the community. Then the 15 interviewers (the same staff members as mentioned above) used mainly their free weekends or sometimes late afternoon hours to conduct the interviews in the assigned buildings. The team leader conducted several control interviews.

\section{Observational study}

During and after the interview additional in-depth interviews were done with the interview partners and the same interviewers conducted participant observations. They were recorded in a field diary and later on ordered in thematic topics and analysed individually and in the group of interviewers.

\section{Data management and analysis}

Interview answers were entered into the computer and analysed using Excel and SPSS software. Results were tabulated and different bar charts developed. A comparative analysis examining the sample characteristics and metal health issues of the two study communities was conducted.

\section{Results}




\section{The study populations}

In the displaced community, 211 families (845 individuals) were interviewed and in the non-displaced population 181 families (732 individuals), i.e. four persons per family in both groups. The direct respondents to the interview were in both communities mainly women at the age of 30 to 50 years, almost all of them with school education. However, in the displaced community, 9.6\% (81) did not comply with the definition of displacement and in the non-displaced community, $12.4 \%$ (91) of families were in fact displaced.

The demographic characteristics for both communities were similar: slight excess of females (female to male ratio 1.04 in the displaced community and 1.1 in the non-displaced) and slight excess of young adults among the displaced compared to the non-displaced $(38.7 \%$ of all ages versus $31.6 \%, p=0.018)$. The proportion of children $<15$ years old was higher among the displaced compared to the non-displaced. With respect to ethnicity, in both groups the mestizo-population (ethnic mixture) was predominant (53.3\% of all families) while the afro-descendants and indigenous people had suffered more frequently from displacement: $28.0 \%$ afro-descendants among the displaced families and $20.4 \%$ among the nondisplaced, $5.7 \%$ of indigenous people among the displaced and $2.2 \%$ among non-displaced $(p=0.052)$. The educational level of persons above 12 years of age including qualified technicians was clearly higher in the non-displaced group (35.6\% of all educational levels) compared to the displaced group (only $15.7 \%$ of all; $p=0.000$ ).

\section{History of displacement}

The peak of the violence in Colombia occurred from 2002 to 2004, which means about 18 years before our survey when our mostly female respondents were about 20 years old. Therefore $55.5 \%$ of the displaced families reported that the event of displacement has happened between 16 to 20 years ago. Only a smaller proportion (19.0\%) had been displaced 11 to 15 years ago and only $9.5 \%$ during the preceding 10 years.

\section{Peoples 'perception of the current situation (qualitative study)}

In the displaced community, the government subsidizes the apartments and the inhabitants did not have to pay a rent. However, there was a continuous feeling of insecurity -as mentioned by most respondentsdue to the open access to the premises, and the existence of gangs of young adults as well as of drug users. The interviewers could witness this; particularly when they arrived in the late afternoon, they saw groups of youngsters and perceived the smell of marihuana. Another problem was the noise which was always present, either loud music or intra-familiar fights or aggression between families. The elected community leaders did not seem to have much authority, as they did not want to accompany the interviewers (mostly females) or introduce them to the families. Taxi drivers could hardly be convinced to enter the compound and bring the interviewers to the buildings because of the bad access road and the feeling of insecurity. In general, families were happy to answer the interview questions. 
In the adjacent buildings of the non-displaced community, the situation was different. The flats were partially subsidized by the government, but the residents had to pay a rent. The residential area was closed for outsiders by a fence and a special permission was required to enter. There was an administrator of the compound who looked over the security and order and controlled entering unknown people. However, the risk of leaving the compound and being attacked on the street was also mentioned. Although the families belonged to the second lowest socio-economic stratum, they felt superior to the adjacent displaced community. Some of them did not want to answer the interview questions due to mistrust.

\section{Experience with violence}

When asked for their exposure to violence, significantly more displaced families had experienced such events $(n=64.0 \%)$ compared to non-displaced families $(n=25.4 \% ; p=0.000)$ (Fig. 2). The responses show that in all categories (intended murder, theft, threat, murder of a family member, kidnapping and sexual violence) the displaced families had to suffer much more frequently than the non-displaced ones. Also, the non-displaced had suffered, although to a less extent, particularly of theft and to less extent of intended murder. Once a violent event has happened, both groups suffered equally of emotional disturbance.

In addition, the intra-familiar violence was clearly more frequent in the displaced community (victims of insults, physical aggression, and armed attacks) compared to the non-displaced community ( $p=0.001$, 0.035 , and 0.001 , respectively; Fig. 3 ). Other causes of human suffering were important life or vital events such as economic problems (affecting $72.5 \%$ of the displaced families compared to $43.1 \%$ of the nondisplaced; $p=0.000$ ). Also severe disease or death of a family member as well as unemployment and severe health problems were more frequent among the displaced families compared to the non-displaced ones (Fig. 4).

\section{Current psycho-emotional status of displaced and non-displaced respondents (Self Reporting} Questionnaire, SRQ; Beusenberg and Orley 1994)

There were 22 different emotional symptoms mentioned: frequent headaches, loss of appetite, sleeplessness, fright, trembling of hands, tension/nervousness, mal-digestion, lack of clear thinking, sadness, does not enjoy daily activities, difficulty to take decisions, difficulty to work, incapable of doing something useful, loss of interest, feels to be useless, suicidal thoughts, feels tired all the time, has unpleasant feelings in the stomach, gets easily tired, feels that somebody has tried to wound her, feels that she is more important than other people think.

$46.4 \%$ of the displaced interviewees and only $20.4 \%$ of the non-displaced suffered seven or more symptoms $(p=0.000)$. Only $6.6 \%$ of the displaced had no symptom at all while among the non-displaced interviewees this was $20.4 \%$ ( $p=0.000$, Fig. 5). 
More than half of the 211 displaced respondents felt symptoms like "get easily frightened" (62.1\%) and "frequent headache" (59.7\%), "feels nervous or tense" (54.0\%), all of them being much rarer than among the 181 non-displaced respondents $(35.9 \%, 43.6 \%$ and $30.4 \%$ respectively; $p=0.000,0.001$ and 0.000 respectively). Other frequent emotional disorders among the displaced interviewees was "feels depressed" (47.9\%), "cannot sleep" (43.6\%) or "cannot think well" (40.8\%) in contrast to the non-displaced participants $(28.2 \%, 22.1 \%$ and $32.0 \%$ respectively; $p=0.000,0.000$ and 0.074 respectively). There were three additional questions on psychotic symptoms ("hears strange voices", "has strange interferences in her thoughts", "has epileptic seizures") but these were rare in both groups although marginally more frequent among the displaced respondents.

\section{Current psycho-emotional status of displaced respondents living in the non-displaced community}

This analysis should help better understand if the emotional problems among displaced respondents are due to the displacement, due to the current living conditions, or due to both.

$40.9 \%$ of the "displaced living among the non-displaced" reported more than seven symptoms in the SRQ. This pattern is more similar to the displaced group than to the non-displaced.

\section{Use of mental health services}

Mental health services were rarely used during the preceding 12 months, both by displaced families $(16.6 \%)$ and non-displaced families $(6.1 \% ; \mathrm{p}=0.000)$. Hospitalizations for mental health problems "once in their lives" were rare exceptions ( $4.7 \%$ among the displaced and $0.6 \%$ among the non-displaced; $p=0.012$ ) keeping in mind that the relative frequency of mental health issues was higher among the displaced compared to the non-displaced populations. The main reason for not using mental health services during the last 12 months were "was not necessary" (39.1\% among the displaced and 71.6\% among the nondisplaced; $p=0.000)$. Other major reasons for not attending mental health services particularly among the displaced families were, service far away, no time, no money, unawareness of my rights, bureaucratic hurdles, distrust.

Most patients attending mental health services went there 3 times or less (12.3\% among displaced persons and $5.0 \%$ among non-displaced; $p=0.001$ ). Patients in both groups went for treatment mainly to hospitals or clinics (56.3\% both groups), but some of them to pharmacies (mainly the non-displaced) or to friends and family members including alternative medicine. Additional consultations for mental health problems were mainly sought by non-displaced patients (28.9\%) and less by the displaced (17.8\%; $p=0.157)$. The treatment costs for displaced patients were mainly borne by the subsidized insurance companies for the displaced patients $(48.9 \%)$ while the treatment of non-displaced patients was mainly financed by the pre-paid insurance companies $(21.1 \%)$ and often through out-of-pocket payment.

\section{Discussion}


The civil war in Colombia - as a prominent example of similar conflicts in our current world- with its peak of violence in the early years of our century is officially over with the peace treaty signed by the government and the most important rebel group FARC in 2016. At the climax of the conflict around 2002, many particularly rural families had to leave their homes and farms due to the threat by major parties of the armed conflict, mainly paramilitary groups in Cesar State. They generally fled to the capital of their State (department) where they finally found a place where to stay, often in a multi-family building provided by the government.

The national survey on mental health in Colombia (ENSM 2015) had shown an overall picture of the mental health status of the nation, distinguishing in some parts of the report between the general and the displaced population. Some but in general not very strong differences have been elucidated between the two groups but naturally at a "macro" level and without adjusting for socio-economic differences. Our study was able to give more detailed insights into the mental health status of two populations with a similar socio-economic status living close to each other but with the distinctive characteristic to belong to the displaced community as against the non-displaced community. Although the event of displacement has happened almost two decades ago, there were still important differences regarding mental health status and associated factors. These will be summarized in the following:

\section{Context and circumstances}

The main traumatizing event (displacement or another violent act) occurred 16 to 20 years before the study. The proportionally most affected groups were Afro-descendants and indigenous people (1.4 times and 3 times higher proportion Afro-Descendant and Indigenous descendants in the displaced compared to the non-displaced population). They all belonged to the lower socio-economic population strata but persons older than 12 years had in the non-displaced population 2.3 times more frequently a secondary education compared with the displaced one.

Mental health status (outcome variable)

Significant differences between displaced and non-displaced families were:

- Currently more frequent emotional problems among displaced persons: higher number of symptoms, particularly frequent being fear, headache, and nervousness but also depression, sleeplessness, and problems to think with clarity

- More family members in the displaced community had experienced some form of violence (64.0\%) compared to the non-displaced community (25.4\%)

- Different forms of violence were more frequently reported by displaced families such as intended murder, threat, murder of a family member and kidnapping (NB. Questions on alcohol or substance abuse could not be asked, as they were perceived to be insensitive according to the pilot tests).

- Threatening life events as stress factors were more frequent in the displaced community: economic problems, severe disease or death of family members, unemployment, or severe diseases 
- The use of mental health services (mainly in hospitals and clinics) was slightly higher by displaced than by non-displaced families ( $16.6 \%$ versus $6.1 \%)$

\section{Determinants}

Living in buildings of the displaced community, a number of stress factors were observed:

- Open access to the premises allowing anybody to enter

- Weak leaders lacking authority

- Youth gangs often involved in drug trade or drug use

- Frequent unemployment

- Noisy neighbours (music, aggressions)

- Poor access road and poor connection with public transport

In contrast, the non-displaced community could live more in peace:

- Closed and protected premises

- Strong authority controlling the access and order

- Better maintenance of the buildings

- Higher employment rates of both men and women

But also:

- Poor access road and poor connection with public transport

- Mistrust and social distancing from the neighbouring displaced community

- Fear of being attacked on the access road

In view of these determinants, it is not surprising that the displaced community living under precarious circumstances continues to be exposed to elevated mental health risks while the neighbouring nondisplaced population can enjoy some basic commodities such as physical protection by a fence, a strong authority that is able to keep order, better maintenance of the building. However, the previous trauma of displacement seems also to persist among displaced families living in the more protected environment of non-displaced families as $40.9 \%$ of the individuals interviewed suffered from more than seven emotional symptoms -which is similar to the displaced respondents living in a more precarious environment (46.4\% with more than seven symptoms).

\section{Recommendations}

Recommendations for the improvement of the living conditions particularly of the displaced population were developed by the State public health and social services based on the findings of the study. To these belong: 
Increase security: Protective fence around the buildings of the displaced community; security guards (watchmen), promote a police station in the area

Reduce violence: Provide opportunities for sport, artwork, dancing, youth clubs, women's` clubs

Promote advanced education and employment: Provide incentives for entering higher education; encourage reading competition for children or storytelling for adults

Offer training on productive work (urban gardening, preparation of food, bakery etc.) to complement the family income.

Improve mental health: strengthen primary mental care in the community through psychologists and social workers.

Other recommendations include:

Special effort to involve those committing violent acts in community activities

Repeat the survey after 3 years to see if changes have taken place.

\section{Limitations of the study}

Although the majority of respondents was happy to answer the interview questions, there was a small number of families who did not want to participate or were absent during the interview. Some response bias was probably due to mistrust and fear. Other contextual factors before and during the displacement process -including disruption of social networks- could not be evaluated. However, in spite of these limitations we are confident that our study results reflect the reality of traumatized people living in quite precarious circumstances compared to others who did not have such a traumatic experience and can live in a more peaceful environment.

\section{Conclusions}

Sixteen to eighteen years after the peak of violence and displacement in Colombia, the victims are still suffering mental hardships (compared to non-victimized persons). Most likely, this is due to the current precarious living conditions but also to the traumatizing events two decades ago.

\section{Abbreviations}

PAPSIV: Program for Attending Psychosocial and Integral Health among Victims

ENSM: Encuesta Nacional de Salud Mental (National Mental Health Survey)

FARC: Fuerzas Armadas Revolucionarias de Colombia (Colombian Revolutionary Armed Forces) 
PAGEL: Partnerships for the Health Sector in Developing Countries

DAAD: The German Academic Exchange Service

\section{Declarations}

\section{Ethics approval and consent to participate}

The interviews were initiated by a standardized description of the aims of the study, the institutions involved, the anonymity (no names were recorded), the right to stop at any time or to skip questions without any harm. No child or adolescent below the age of 18 was interviewed in this study. The consent was obtained verbally as under the given circumstances a written consent was not possible and not recommended by the community leaders. The procedure was checked by the supervisor and the consent to participate statement and ethical considerations were approved by the ethical committee of Pontificia Javeriana University. The ethical committees of Pontificia Javeriana University and Freiburg University approved the project on 07.03.2018 stating that the approval was based on "the pertinence of the investigation, the methodological rigor, its scientific quality, the coherence and adequacy of the proposed budget and the fulfilment of scientific, technical and ethical norms". The local health authorities accepted the approvals after a detailed presentation of the study.

\section{Consent for publication}

Not applicable

\section{Availability of data and materials}

The datasets used and/or analysed during the current study are available from the corresponding author on reasonable request.

\section{Competing interests}

The authors declare that they have no competing interests.

\section{Funding}

Supervision travels by SDM and AK and the transport of the interviewers to the study neighbourhoods was financed by PAGEL programme.

The article processing charge was funded by the German Research Foundation (DFG) and the University of Freiburg in the funding programme Open Access Publishing.

Author's contributions

SDM, AMV, JEA, YNF and AK designed the study, did the interviewer training, and drafted the paper. All authors read and approved the study and the procedures. AMV, YNF, EPQ and AFCN prepared the 
submission to the ethical committee and prepared the logistics. JEA, AMO, ARRV, JCBC, LAZ prepared the field study, contacted the local leaders, organized the logistics. All authors read and commented on the draft paper and approved the final version

\section{Acknowledgements}

The German Academic Exchange Service (DAAD) in the context of the PAGEL programme facilitated this work. We are grateful to our co-interviewers for their patience and excellent work under difficult circumstances, particularly to Electa de Jesús Arzuaga Villero, Cecilia Flórez Sanchez, Yusleydis Gutiérrez Ospino, Sunilda María López Blanco, Yarima Vanessa Martínez Castilla, Olga Beatriz Ochoa Díaz, Martha Leonor Romero Orozco, Yerlis Saenz Arias, Nora Inmaculada Santos and Zuleima María Billa Jimenez. We thank Freiburg University for supporting the publication of this study. We are particularly obliged to all our respondents who took the time and had the courage to answer our questions.

\section{References}

Análisis de Situación de Salud con el Modelo de los Determinantes Sociales de Salud de Cesar (ASIS 2016). Cesar, Colombia: Secretaria de Salud Departamental del Cesar. Available from: https://www.minsalud.gov.co/sites/rid/Lists/BibliotecaDigital/Forms/DispForm.aspx?ID=16138

Protocolo de Atención Integral en Salud con enfoque psicosocial para las personas víctimas del conflicto armado en Colombia. (2013) Bogotá: Ministerio de Salud y Protección Socia. Available from: https://www.minsalud.gov.co/proteccionsocial/Paginas/Victimas_PAPSIVI.aspx

Ardón Centeno, N., \& Cubillos Novella, A. (2012). La salud mental: una mirada desde su evolución en la normatividad colombiana. 1960-2012. Revista Gerencia y Políticas de Salud, 11(23). Available from: http://revistas.javeriana.edu.co/index.php/gerepolsal/article/view/4456

Beusenberg, M., Orley, J. H.(editors) (1994). A User's guide to the self-reporting questionnaire (SRQ) WHO/MNH/PSF/94.8. Geneva: World Health Organization.

De los Psicólogos, P. É. Código de Conducta de la American Psychological Association (APA): Versión 2002. vigencia 1/3/2003. Traducción en español: G. Salomone y JJ Michel Fariña. En IBIS (International Bioethical Information Sistem). Hipertexto e hipermedia sobre ética profesional. Sistema Multimedial en CD-ROM. Versión 1.5.

Fronteras, M. S. (2013). Las heridas menos visibles: Salud mental, violencia y conflicto armado en el sur de Colombia. Médicos Sin Fronteras. Available from: http://psiquiatria.org.co/web/wpcontent/uploads/2013/06/Las-Heridas-Menos-Visibles-Reporte-MSF-2013.pdf

Encuesta Nacional de Salud Mental (2015). Bogotá, Colombia: Colciencias, Ministerio de Salud y Protección Social y Pontificia Universidad Javeriana. Available from: 
https://www.javerianacali.edu.co/sites/ujc/files/node/field-

documents/field_document_file/saludmental_final_tomoi_color.pdf

Encuesta Nacional de Salud Mental (2015). Instrumentos de Recolección ENSM 2015.Bogotá, Colombia: Colciencias, Ministerio de Salud y Protección Social y Pontificia Universidad Javeriana. Ministerio de Protección social y Fundación FES Social (2003). Estudio Nacional De Salud Mental. Colombia 2003. Available from: https://www.minsalud.gov.co/Documentos\%20y\%20Publicaciones/

ESTUDIO\%20NACIONAL\%20DE\%20SALUD\%20MENTAL\%20EN\%20COLOMBIA.pdf

Ministerio de Salud (1993). Resolución 8430 de 1993. Por la cual se establecen las normas científicas, técnicas y administrativas para la investigación en salud. Available from: https://www.minsalud.gov.co/sites/rid/Lists/BibliotecaDigital/RIDE/DE/DIJ/RESOLUCION-8430-DE1993.PDF

Ministerio de Salud y Protección social \& Organización Internacional para las Migraciones (2018). Proyecto tipo en salud mental y construcción de paz. Convenio 547 de 2015 Celebrado entre el Ministerio de Salud y Protección Social y la Organización Internacional para las Migraciones. Available from: https://www.minsalud.gov.co/sites/rid/Lists/BibliotecaDigital/RIDE/VS/MET/Proyecto-tipo-saludmental-construccion-paz.pdf

Mundial, A. M. (2008). Declaración de Helsinki de la Asociación Médica Mundial. Principios éticos para las investigaciones médicas en seres humanos. In Anales del Sistema Sanitario de Navarra (Vol. 24, No. 2, pp. 209-212).

Registro Único de Victimas (RUV) 2017-2018. Available from:

https://www.unidadvictimas.gov.co/es/registro-unico-de-victimas-ruv/37394

Secretaría de salud de Bogotá (2016). Política Distrital de Salud Mental 2015-2025. Alcaldía mayor de Bogotá. Available from:

http://www.saludcapital.gov.co/Documents/Transparencia/3_Politica_de_Salud_Mental.pdf

\section{Figures}



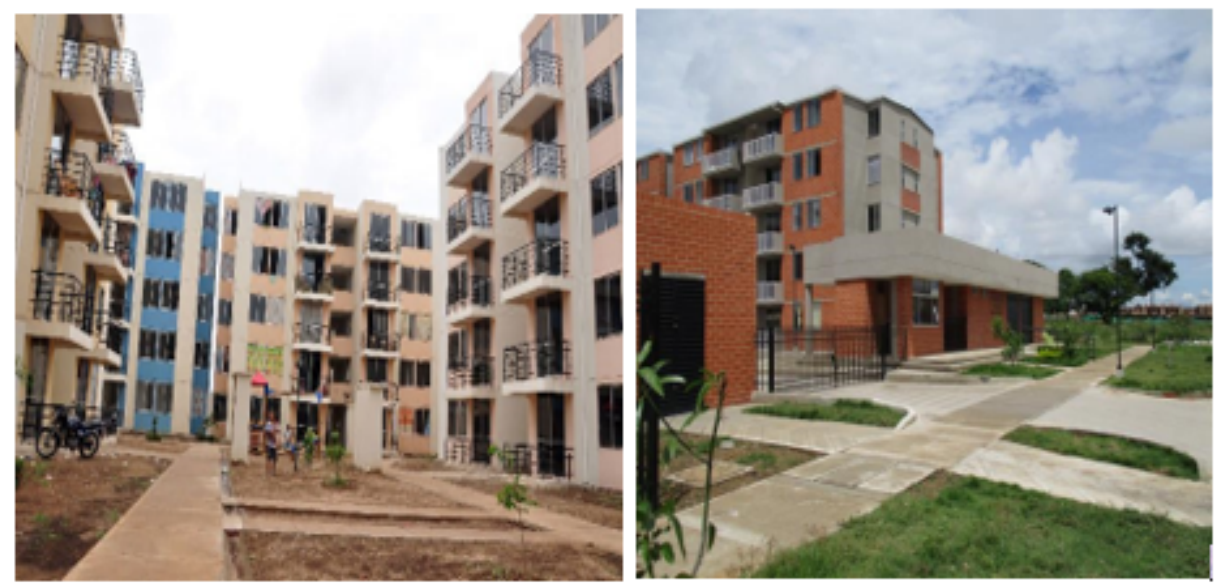

\section{Figure 1}

Compound of displaced families (left) and non-displaced families (right)

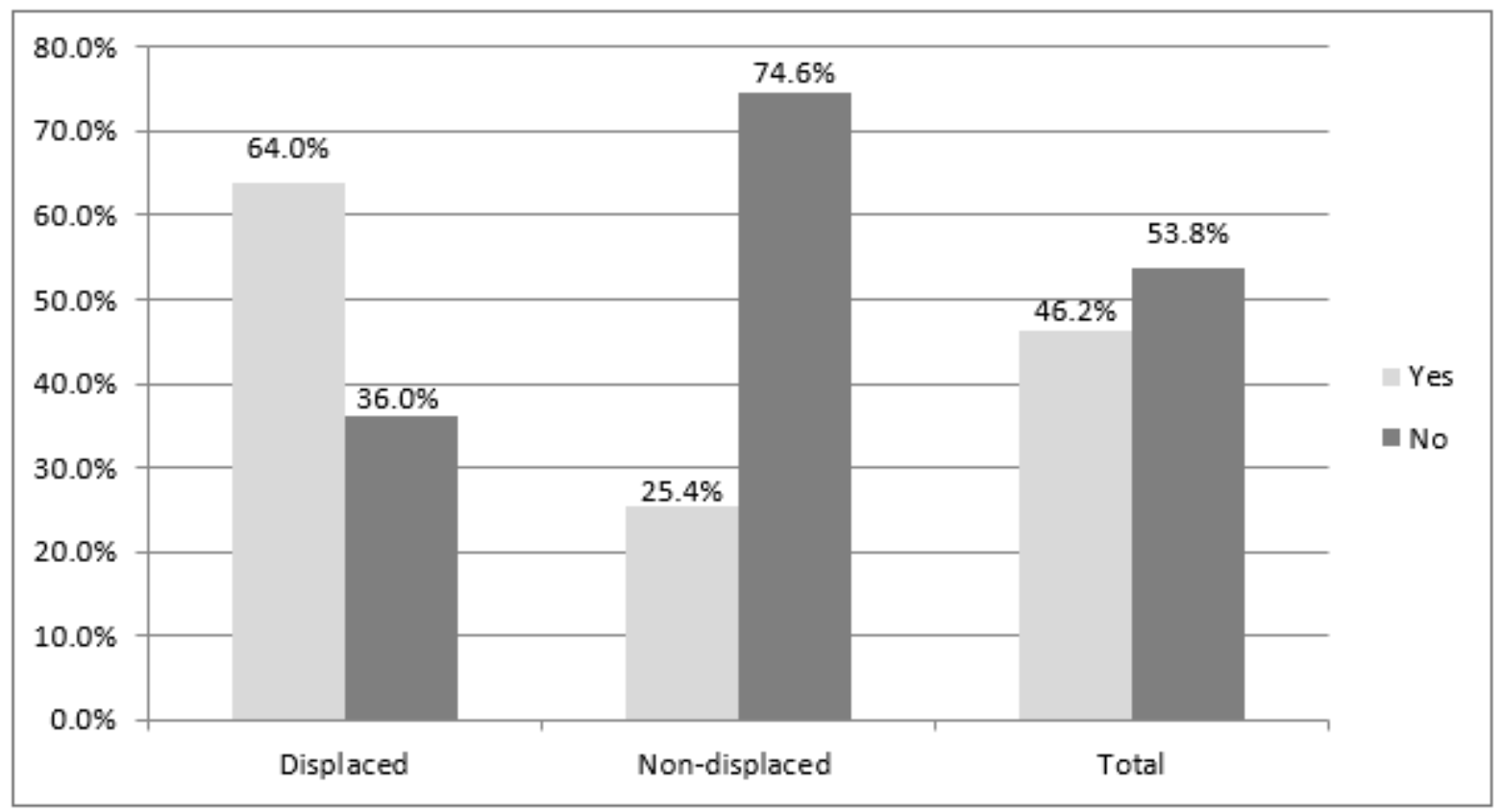

Figure 2

Victims of violence in displaced and non-displaced families. 


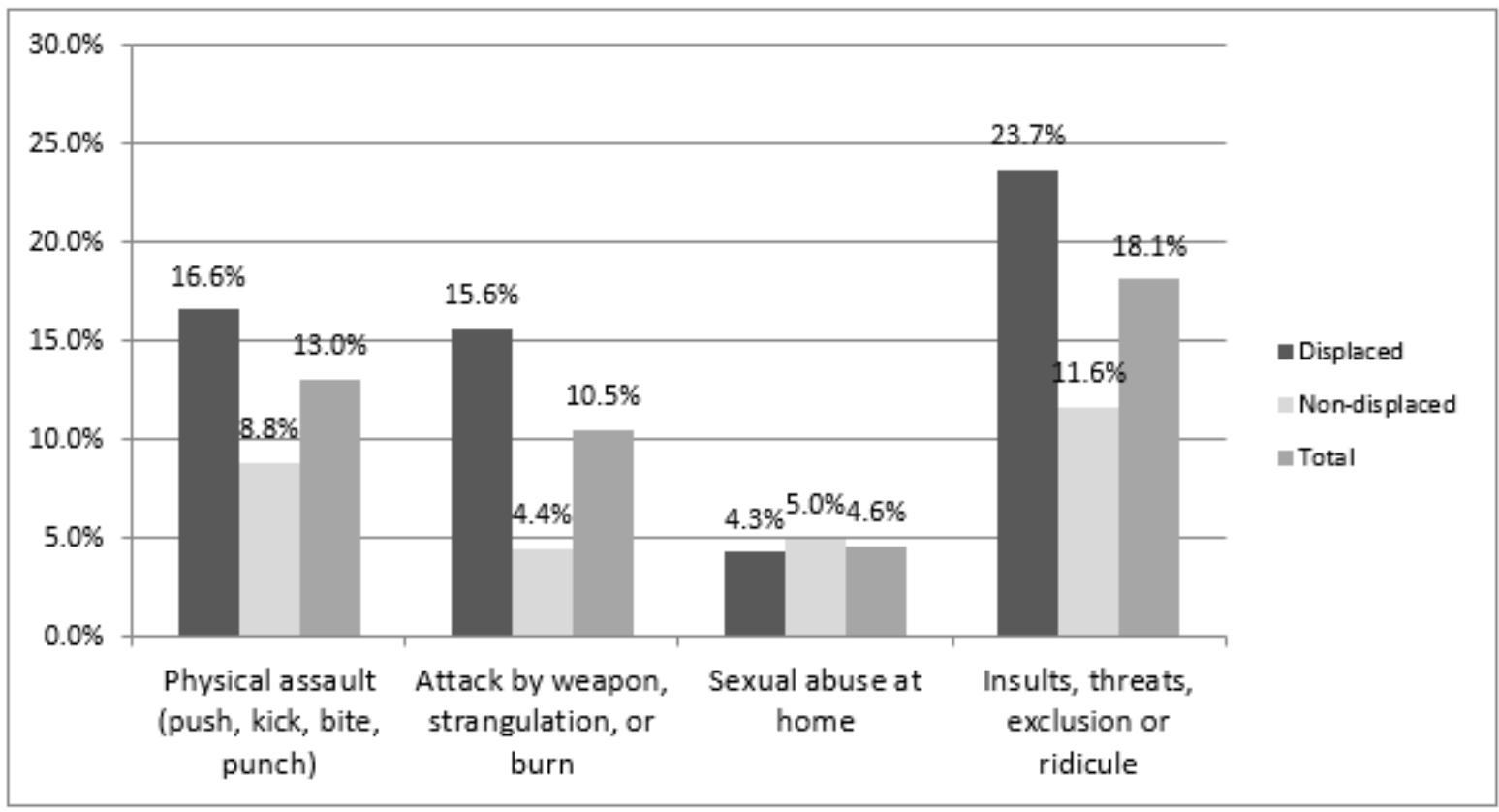

\section{Figure 3}

Intra-family violence among displaced and non-displaced families.

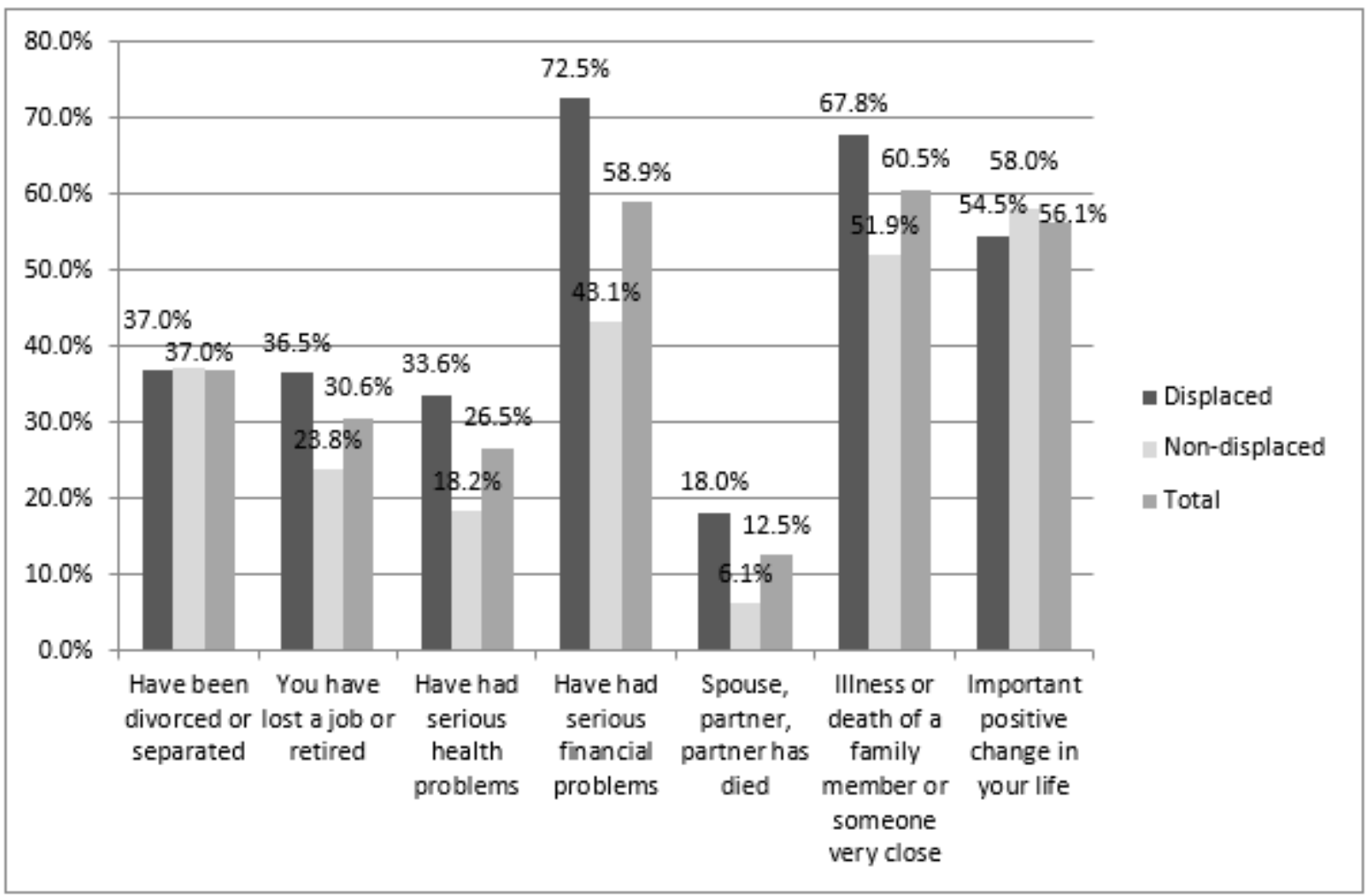

Figure 4

Life events among displaced and non-displaced families 


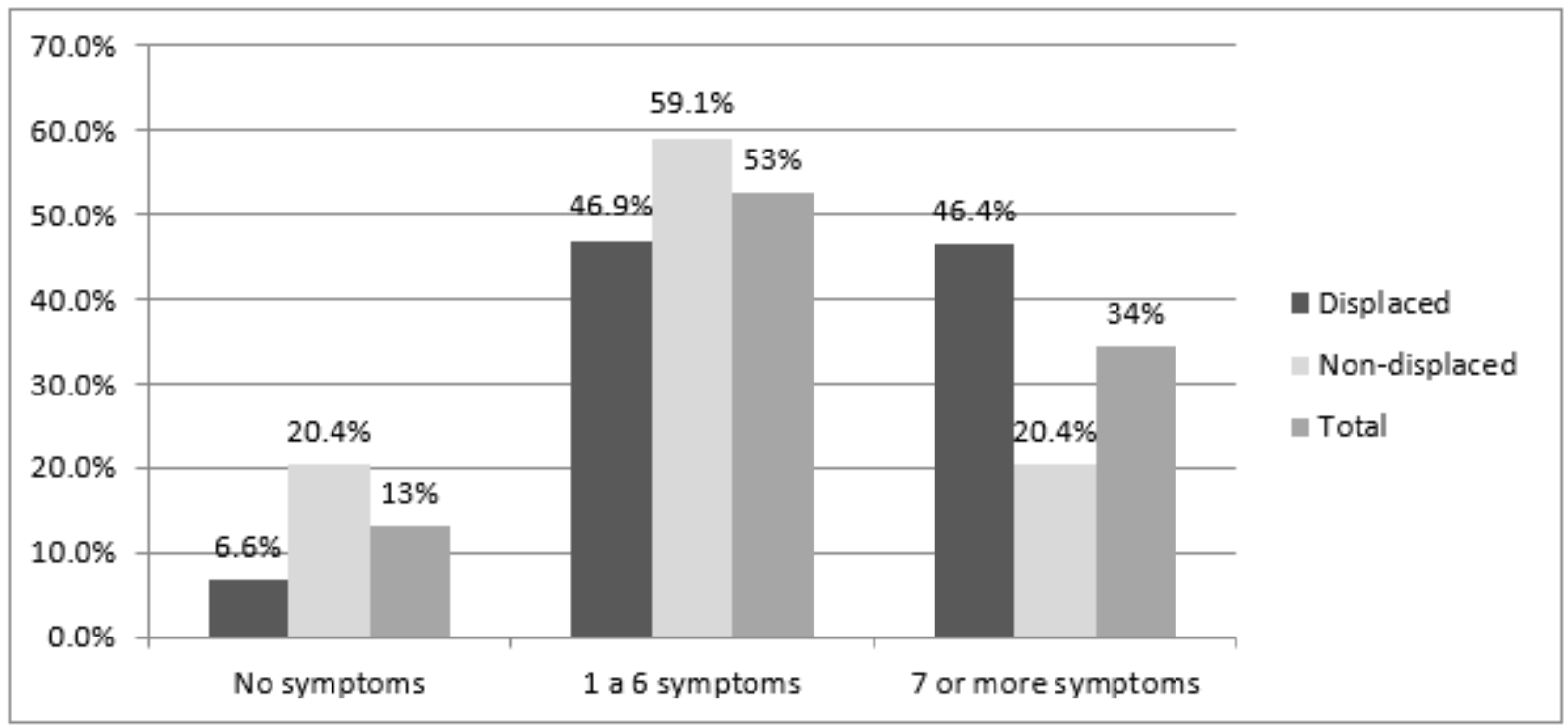

Figure 5

Number of emotional symptoms reported in the SRQ by formerly displaced and non-displaced individuals

\section{Supplementary Files}

This is a list of supplementary files associated with this preprint. Click to download.

- Additionalfile1.pdf 